\title{
PRODUCTION OF LETTUCE CROP UNDER FOLIAR ORGANO-MINERAL FERTILIZATION AND ENVIRONMENT
}

\author{
PRODUÇÃO DA ALFACE CULTIVADA SOB FERTILIZAÇÃO ORGANOMINERAL \\ VIA FOLIAR E AMBIENNCIA
}

\section{Luiz Leonardo FERREIRA ${ }^{1}$; Alexandre Igor Azevedo PEREIRA ${ }^{2}$; Carmen Rosa da Silva CURVÊLO ${ }^{2}$, Francisco Vanies da Silva SÁ ${ }^{3}$; Nildo da Silva DIAS ${ }^{4}$; Rene Chipana RIVERA ${ }^{5}$; Cleyton dos Santos FERNANDES 6}

1. Professor Doutor da Universidade Estadual de Goiás, Centro Universitário de Mineiros, Mineiros, GO, Brasil; 2. Professor(a) Doutor(a) do Instituto Federal Goiano-Campus Urutaí, Campus Urutaí, Urutaí, GO, Brasil; 3. Doutor em Engenharia Agrícola, PósDoutorando em Manejo de Solo e Água PNPD/CAPES, Universidade Federal Rural do Semi-Árido - UFERSA, Mossoró-RN, Brasil;4. Professor Doutor da UFERSA, Mossoró-RN, Brasil, nildo@ufersa.edu.br; 5. Professor da Facultad de Agronomía de la Universidad Mayor de San Andrés, La Paz, Bolívia; 6. Doutorando em Fitotecnia, UFERSA, Mossoró-RN, Brasil.

\begin{abstract}
The objective of the present work was to evaluate the effect of the organo-mineral foliar fertilization and the environment in the lettuce crop. The work was carried out in a soil classified as Quartzipsamments, with loam texture and low initial availability of nutrients. The experimental design used was randomized blocks with a factorial arrangement $2 \times 2 \times 5$, corresponding to two cultivars of lettuce (Crisp Vanda and Crisp Lucy Brown), two environments (with and without shading mesh at 35\%) and five concentrations of Ferti Garden liquid fertilizer multipurpose via foliar, $(0 ; 5 ; 10 ; 15$ and $20 \%$ of the product in the solution), with 4 repetitions, containing 20 plants. Soil preparation was done manually and fertilized with $30 \mathrm{~m}^{3}$ hectare ${ }^{-1}$ of bovine manure, dead cover was also used. The foliar fertilizer was applied three times, at intervals of seven days, through a constant pressure sprayer, from 12 days after transplanting the seedlings. At 33 days after the transplant the plants were harvested and evaluated in the variables of head diameter, number of leaves, fresh matter and productivity. The cultivar Crisp Lucy Brown proved to be more demanding in terms of luminosity and mineral nutrition in relation to the cultivar Crisp Vanda. Therefore, the highest development and productivity of the Crisp Lucy Brown cultivar is obtained without shading mesh, with fertilization before sowing of $30 \mathrm{~kg} \mathrm{ha}^{-1}$ of fowl bed and fertilization with $9.1 \%$ of the foliar fertilizer. While for the cultivar Crisp Vanda the highest productivity is obtained with shading mesh, and only with fertilization before sowing.
\end{abstract}

KEYWORDS: Lactuca sativa. Shading mesh. Mineral nutrition. Growth. Production.

\section{INTRODUCTION}

The production of vegetables in Brazil is distributed throughout the territory, with lettuce (Lactuca sativa $\mathrm{L}$.) one of the most consumed daily by the Brazilian population, due to its importance as a source of vitamins, minerals and fibers (SANTI et al. al., 2010). Therefore, this vegetable occupies a prominent place in terms of volume produced and global and national consumption. Due to aspects related to its perishability, the lettuce is produced in areas near to consumption centers, in different regions of the country, throughout the year, mainly by small farmers (FREITAS et al, 2013).

The production of lettuce, like any other agricultural crop, requires for its development the full use of adequate techniques and technologies so that the crop is developed in different regions of the country, without prejudice to the farmer (LUZ et al., 2010). In this sense, studies are needed focused on the development of new production systems, establishment of suitable varieties and levels of fertilization, in such a way that the farmer is guaranteed to get adequate profitability with this activity, as well as the establishment of a crop management system that allows reaching the productive potential of the lettuce crop (HIREL et al., 2011).

In terms of fertilization, for the modernization of agriculture it is necessary to set aside the conventional crop and instead use strategies that offer better nutritional balance and so higher crop productivity. For this, we must use advanced technologies that have been adopted in the phytotechnical management of some crops and the application of plant regulators and foliar fertilizers (LUZ et al., 2010; IZIDÓRIO et al., 2015). The substitution of conventional fertilization carried out before and after sowing, by foliar organo-mineral fertilization in short-cycle crops such as lettuce, in 
addition to reducing the risk of contamination of the soil and the water table, can increase the efficiency of fertilization and so the yield, minimizing the costs of mineral fertilizers (MATOS et al., 2017).

In addition to fertilization, improvements in the environmental conditions of the crop, such as the use of shading meshes, help control the luminosity and temperature, which have a complex influence on the production of the plants, considering that the increase in solar radiation can increase the photosynthetic activity and the growth of plants (PEREIRA et al., 2015). However, excess radiation raises the transpiration rate, which could cause stomatal closure and decrease in photosynthesis, in addition to the high insolation, usually associated with high temperatures, which could induce an increase in photorespiration affecting negatively the growth of the plant (OTONI et al., 2012). Therefore, the use of shading meshes provides proper microclimatic conditions for crop development (RAMPAZZO et al., 2014).

In this sense, the objective of this research was to evaluate the influence of foliar organomineral fertilization and the environment on the lettuce crop.

\section{MATERIAL AND METHODS}

The study was conducted at the Luiz Eduardo de Oliveira Sales Experimental Farm, in the municipality of Mineiros-GO, located between the geographic coordinates of $17^{\circ} 34^{\prime} 10^{\prime}$ ' South latitude and $52^{\circ} 33^{\prime} 04^{\prime}$ ' west longitude, with altitude mean of $760 \mathrm{~m}$. During the experiment, mean temperature data equal to $22.6{ }^{\circ} \mathrm{C}$, relative air humidity of $80.83 \%$, dew point of $18.63{ }^{\circ} \mathrm{C}$, atmospheric pressure of $934.39 \mathrm{hPa}$, wind speed of $0.85 \mathrm{~m} \mathrm{~s}^{-1}$, solar radiation of $1031.47 \mathrm{~kJ} \mathrm{~m}^{-2}$ and rainfall of $0.08 \mathrm{~mm}$, were recorded. The zone of the place is classified as climate of type Aw (hot to dry). The soil was classified as Quartzipsamments, with loam texture, slightly undulating to flat topography and limited drainage (SANTOS et al., 2013).

Before the implementation of the experiment, soil analysis was performed in the 0-20 $\mathrm{cm}$ layer, observing the following characteristics: clay $=223 \mathrm{~g} \mathrm{dm}^{-3}$, silt $=50 \mathrm{~g} \mathrm{dm}^{-3}$, sand $=728 \mathrm{~g} \mathrm{dm}^{-}$ 3 , potential of hydrogen $=5.7$; calcium $=3.0 \mathrm{cmol}_{\mathrm{c}}$ $\mathrm{dm}^{-3}$, magnesium $=0.8 \mathrm{cmol}_{\mathrm{c}} \mathrm{dm}^{-3}$, aluminum $=0.2$ $\mathrm{cmol}_{\mathrm{c}} \mathrm{dm}^{-3}$, hydrogen + aluminum $=2.0 \mathrm{cmol}_{\mathrm{c}} \mathrm{dm}^{-3}$, cation exchange capacity $=5.9 \mathrm{cmol}_{\mathrm{c}} \mathrm{dm}^{-3}$; potassium $=53.0 \mathrm{mg} \mathrm{dm}^{-3}$, phosphorus $=59.0 \mathrm{mg}$ $\mathrm{dm}^{-3}$, sulfur $=1.7 \mathrm{mg} \mathrm{dm}^{-3}$, boron $=0.2 \mathrm{mg} \mathrm{dm}^{-3}$, copper $=1.4 \mathrm{mg} \mathrm{dm}^{-3}$, iron $=51.0 \mathrm{mg} \mathrm{dm}^{-3}$, manganese $=23.0 \mathrm{mg} \mathrm{dm}^{-3}$, zinc $=8.3 \mathrm{mg} \mathrm{dm}^{-3}$, sodium $=1.5 \mathrm{mg} \mathrm{dm}^{-3}$, organic matter $=20.0 \mathrm{~g} \mathrm{dm}^{-3}$ and organic carbon $12.0 \mathrm{~g} \mathrm{dm}^{-3}$. As well as in the fowl bed: nitrogen $=3.0 \%$, magnesium $=1.1 \%$, phosphorus $=3.0 \%$, potassium $=4.6 \%$, sulfur $=$ $0.45 \%$, organic matter $=65.1 \%$, calcium $=5.3 \%$, humidity $16.7 \%$, cobalt $0.1 \mathrm{ppm}$ and molybdenum $0.1 \mathrm{ppm}$. The data were analyzed considering the method proposed by Donagema et al. (2011).

The experimental design used was randomized blocks with a factorial arrangement $2 \mathrm{x}$ $2 \times 5$, corresponding to two cultivars of lettuce (Crisp Vanda and Crisp Lucy Brown), two production environments (with and without of shaded mesh at 35\%) and five concentrations Ferti Garden liquid fertilizer for via foliar $(0 ; 5 ; 15$ and $20 \%$ of the product in the solution), with four repetitions, totaling 20 treatments and 80 experimental units, where each plot had was composed of 20 plants and dimensions of $0.80 \mathrm{~m} \mathrm{x}$ $1.20 \mathrm{~m}$ with area of $1 \mathrm{~m}^{2}$ plot $^{-1}, 0.3 \mathrm{~m}^{2}$ of floor area and $80 \mathrm{~m}^{2}$ of total area.

Crisp Vanda lettuce has as main characteristics a variety developed in Brazil, be adapted to tropical conditions, have a thick stalk, resistance to calcium deficiency and mosaic virus, vigorous root system, adaptation to open field cultivation and hydroponics and precocity of approximately 5 days. The American lettuce Lucy Brown is a plant of high vigor and good foliar sanity. It has large head and thick leaves of light green color, with good compaction and weight. This lettuce cultivar is tolerant to early weeding.

During the preparation of the soil the demarcation of the beds was made, later its configuration with manual hoe. It was distributed homogeneously in the beds $30 \mathrm{~m}^{3}$ hectare $^{-1}$ of fowl bed with the help of a rake on the entire surface. Dry vegetable straw was then used as a cover for the soil with the purpose of minimizing the incidence of invasive plants and providing physical protection to the soil. Then the transplant was performed on 04/16/2017, using 20 seedlings per plot, arranged in spacing of $0.20 \mathrm{~m} \times 0.20 \mathrm{~m}$, acquired in authorized trade.

The application of fertilizers began on 04/28/2017, repeating twice at seven-day intervals. For this, a constant pressure sprayer was used, provided with a cone-type spray tip, applying a dose of $150 \mathrm{~L} \mathrm{ha}^{-1}$ of fertilizer solution. The applications were made during the morning, with ambient temperature of $25^{\circ} \mathrm{C}$, relative humidity of the air above $60 \%$ and winds of less than $5 \mathrm{~km} \mathrm{~h}^{-1}$. Ferti Garden liquid fertilizer is a balanced mixture of organic and mineral materials, with formulation of 
$\mathrm{NPK}+\mathrm{C}=10-6-6+6$, which results in greater use of macronutrients.

The irrigations were manually adjusted, and the applied blade was based on reference evapotranspiration (ETo), calculated by the Penman-Monteith model (Allen et al., 1998). The calculation of the gross blade was performed according to Mantovani et al. (2006). The climatologic data used to calculate ETo were collected daily at the agrometeorological station located near the experimental area.

The study variables were analyzed after harvest on 05/19/2017. For this, the diameter of the head was measured (with a tape measure), number of leaves per plant (by manual counting), fresh matter was determined by weighing the aerial part of the plants in analytical balance and the productivity of the lettuce crop, according to the method proposed by Benincasa (2003).

The results were analyzed statistically by the analysis of variance. The description of the variables was made according to the concentration of the foliar fertilizer. To do this, we performed polynomial regressions, testing linear and quadratic models, selecting the models that presented the highest correlation value with respect to the means, based on the level of significance of the F test. The comparison between cultivars and the environment was also carried out with the Tukey test at 5\% probability. The analyzis were carried out with the statistical program System for Analysis of Variance - SISVAR 5.6 (FERREIRA, 2011).

\section{RESULT AND DISCUSSION}

A significant effect was observed in the interaction between cultivars $\mathrm{x}$ environment $\mathrm{x}$ Ferti Garden dose at the $5 \%$ probability level $(\mathrm{p}<0.05)$ for all the variables studied. In the diameter of the head of lettuce, a quadratic trend was observed for the cultivar Crisp Lucy Brown cultivated under shading mesh (RP) and in the absence of shading mesh (RA) and Crisp Vanda in shading mesh, with the estimated doses of fertilizer $8.63 ; 9.03$ and $7.98 \%$ provided the largest head diameters 41.33 , 46.19 and $57.88 \mathrm{~cm}$, respectively. According to Farias et al. (2017), the use of organic fertilizers is fundamental to improve the development of lettuce, since the addition of organic compounds increased the growth and production of lettuce cv. Babá de Verão.

It was also verified that in the SP treatment, the largest head diameters were obtained with respect to the other treatment, for all the doses of fertilizer studied (Figure 1A). While the cultivar Crisp Vanda in the absence of shading mesh, was not affected by foliar fertilization, obtaining an mean of $35.78 \mathrm{~cm}$, the lowest value among the treatments. Which indicates that the sensitivity of the cultivar to excess luminosity. These results agree with those obtained by Bezerra Neto et al. (2005), who observed that the transparent mesh provided increases in height and head diameter of lettuce plants in relation to full sun.
A

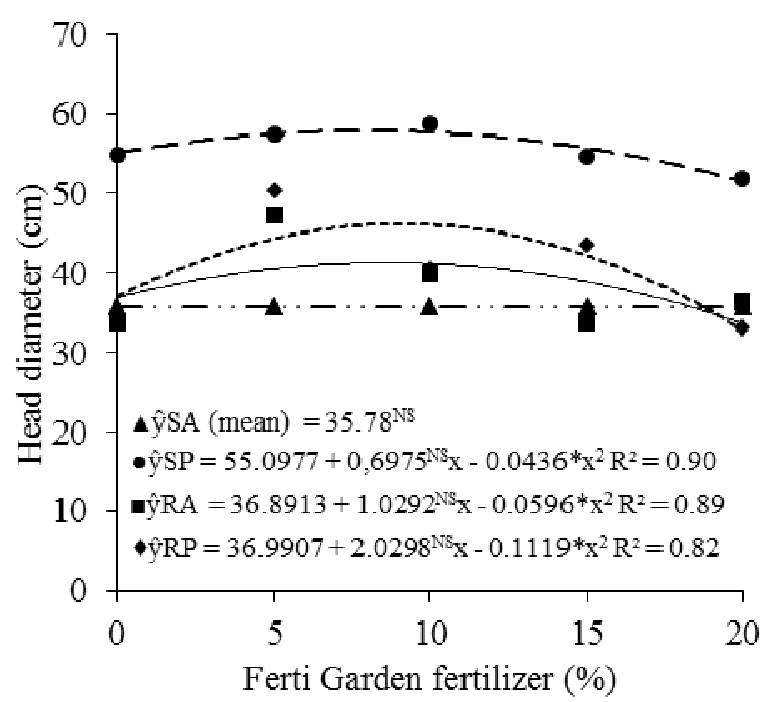

B

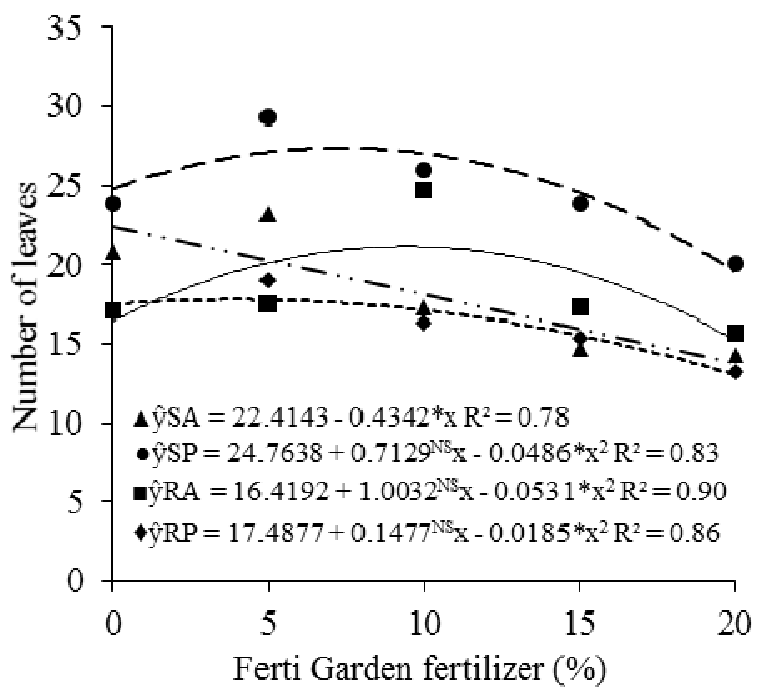

$* \mathrm{e}^{\mathrm{NS}}=$ Significant at $5 \%$ probability and not significant, respectively.

Figure 1. Head diameter (A) and number of leaves per plant (B) of cultivars (R -Crisp Lucy Brown; S -Crisp Vanda) of lettuce under Ferti Garden fertilizer applied via foliar in the presence - P and absence - A, of shading mesh. 
Regarding the number of leaves per plant, it was observed that for the treatments RA, RP and $\mathrm{SP}$, there was a quadratic tendency based on Ferti Garden doses, with the highest rates observed under the doses of $9.44 ; 3.98$ and $7.32 \%$, corresponding to $21.15 ; 17.78$ and 27.37 leaves plant ${ }^{-1}$, respectively (Figure 1B). For the SA treatment a decreasing linear effect was observed, which indicates that foliar fertilization with Ferti Garden causes growth reduction, probably caused by physiological disorders associated with the sensitivity of the cultivar at high rates of insolation and temperature (OTONI et al., 2012; RAMPAZZO et al., 2014). So it can be inferred that the morphological characteristic of rolling leaves for head formation, observed in the cultivar Crisp Lucy Brown, protects leaves from excess insolation, responding positively to foliar fertilization in relation to the cultivar Crisp Vanda, in absence of shade.

The lettuce crop cv. Crisp Vanda in shaded environment allowed the emission of a greater number of leaves than in the other treatments, independently of the dose of Ferti Garden applied via foliar, especially when compared with results of the same cultivar, but in the absence of shading mesh (Figure 1B). This fact indicates that the Crisp Vanda cultivar is more sensitive to luminosity and temperature than the Crisp Lucy Brown cultivar, being necessary to use a shading mesh to get a satisfactory development. The results obtained in the present investigation are similar to those achieved by Ricardo et al. (2014) in the city of Registro-São Paulo, where in all the lettuce cultivars studied they obtained better performance under limited radiation conditions (presence of shading mesh). The results observed also corroborate those of Radin et al. (2004), which show that the plants in the shading system tend to have a greater number of leaves and foliar area to those that grow in full sunlight, confirming the sensitivity of the lettuce crop to the excess of solar radiation.

For fresh matter, a decreasing linear trend was observed for the SA and SP treatments, according to the Ferti Garden dose increase, with reductions of 0.0244 and $0.0322 \mathrm{~kg}$ for each $1 \%$ increase in Ferti Garden dose (Figure 2A). For the RA and RP treatments, a quadratic behavior was observed for the accumulation of fresh matter under the doses of 9.12 and $5.50 \%$, providing 1.10 and $0.75 \mathrm{~kg}$ of fresh matter per plant, respectively (Figure 2A). It was also verified that the Ferti Garden foliar fertilizer did not positively influence the accumulation of fresh matter in the lettuce plants cv. Crisp Vanda, which may be related to the lower nutritional need of this cultivar in relation to $\mathrm{cv}$. Crisp Lucy Brown, since as well as to having more leaves, lettuce plants cv. Crisp Vanda are sensitive to cultivation in full sun. In addition this cultivar cultivated under shading mesh and only with fertilization before planting gave greater accumulation of fresh matter. In this way it is verified that the use shading mesh (protected environment) is favorable and produces good results in the cv. Crisp Vanda, confirming that the control of solar radiation allows an increase in the production of phytomass (SCHOENINGER et al., 2011).
A

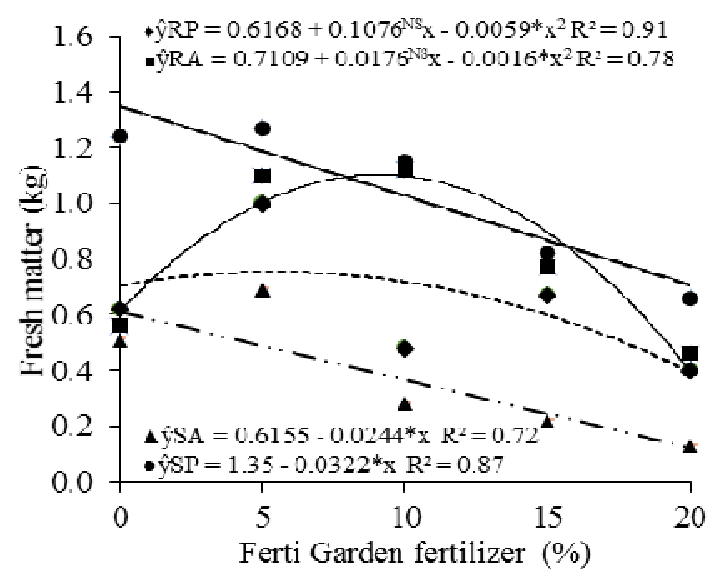

B

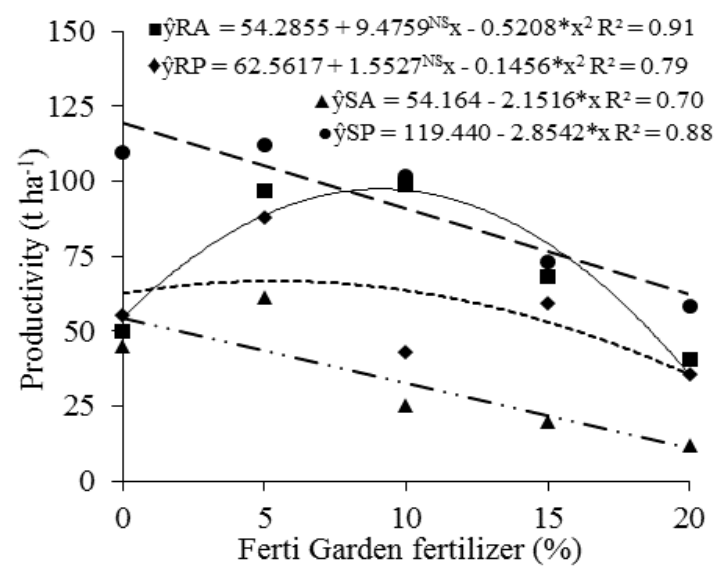

$* \mathrm{e}^{\mathrm{NS}}=$ Significant at $5 \%$ probability and not significant, respectively.

Figure 2. Fresh matter per plant (A) and productivity (B) of cultivars ( $\mathrm{R}$ - Crisp Lucy Brown, $\mathrm{S}$ - Crisp Vanda) of lettuce under Ferti Garden fertilizer applied via foliar in the presence - P and absence - A, shading mesh. 
The lettuce crop cv. Crisp Lucy Brown, under full sun conditions associated with foliar fertilization, had an increase in the accumulation of fresh matter compared to plants grown in shade, which indicates that this cultivar is demanding the incidence of light and mineral nutrition. According to Taiz et al. (2015), the leaves that grow in shaded environment have more chlorophyll per reaction center, being less thick and larger area than those developed in full sun. Therefore, the results of efficiency in the use of fertilizer could have been affected by the increase in the incidence of light.

The productivity of lettuce cv. Crisp Vanda decreased linearly in the treatments with presence and absence of shading mesh, having obtained reductions of 2.85 and $2.15 \mathrm{t} \mathrm{ha}^{-1}$ for each unit increase in the dose of Ferti Garden (Figure 2B). The use of shading mesh associated with the low nutritional need of cv. Crisp Vanda compared with the cv. Crisp Lucy Brown, allowed to get a satisfactory production of this cultivar only with fertilization before sowing ( $30 \mathrm{~kg} \mathrm{ha}^{-1}$ of fowl be). It is important to note that with shading mesh the productivity of said cultivar was twice as high as the productivity in the absence of shading mesh. For Kitao et al. (2000), excess radiation can reduce the productivity of plants, attributed to the phenomenon of photoinhibition. The increase in the productivity of lettuce with the use of meshes to minimize insolation, was also observed by Guerra et al. (2017) in the lettuce cv. Crespa Elba.

For the cv. Crisp Lucy Brown observed a quadratic behavior of the crop productivity as a function of fertilization of Ferti Garden, in the absence and presence of shading mesh, with the highest productivities equal to 97.38 and $66.70 \mathrm{t} \mathrm{ha}^{-}$ 1 , for the doses of 9.10 and $5.33 \%$ of the foliar fertilizer (Figure 2B). This result is like that obtained by Luz et al. (2010), where the products used in the fertilization of the crop had positive results in productivity.

When evaluating the effect of the shading mesh on the nutritional aspects of lettuce, Silva et al. (2016) verified that the use of mesh at 50\% shading caused increase in foliar contents of $\mathrm{N}, \mathrm{P}$, $\mathrm{K}, \mathrm{Ca}$ and $\mathrm{Mg}$ in three cultivars of lettuce ('Delícia', 'Babá de Verão' e 'Itapuã 401'). Therefore, it is likely that the lower need of plants cv. Crisp Lucy Brown to the foliar fertilizer in the presence of mesh, occurs due to the improvement of that practice in the nutritional aspects of the plants. However, due to the greater demand for insolation observed in cv. Crisp Lucy Brown in relation to cv. Crisp Vanda, the use of shading mesh reduced in $31.5 \%$ the productivity of said cultivar (Figure 2B).

In the environment without shading mesh the Crisp Lucy Brown cultivar was superior to Crisp Vanda cultivar in all the evaluated variables, with productivity standing out with mean values of 66.70 $\mathrm{t} \mathrm{ha} \mathrm{a}^{-1}$, while for the second it was $54.16 \mathrm{t} \mathrm{ha}^{-1}$. However, in this variable it was observed that in shading mesh environment the Crisp Vanda cultivar showed higher levels of productivity reaching values of $119.44 \mathrm{t} \mathrm{ha}^{-1}$, higher in $22.06 \mathrm{t} \mathrm{ha}^{-1}$ with respect to the Crisp Lucy Brown cultivar. The results observed in the present investigation show that the responses to environmental conditions of lettuce cultivation vary within the same species, being the cultivar Crisp Vanda moderately demanding to luminosity and mineral nutrition, in comparison to the cultivar Lucy Brown.

For the accumulation of dry matter is observed interaction between the cultivars vs shading, and it was verified that the Crisp Vanda presented reduced phytomass accumulation in relation to the cultivar Crisp Lucy, when submitted to conditions of absence of Shading mesh (Table 1). In the presence of Shading mesh there was no significant difference between the cultivars, indicating that the cultivar Crisp Vanda is sensitive to the high incidence of light. The excess radiation raises the transpiration rate, which could cause stomatal closure and decrease in photosynthesis, in addition to the high insolation, usually associated with high temperatures, which could induce an increase in photorespiration affecting negatively the growth of the plant (OTONI et al., 2012).

Table 1. Dry matter of cultivars of lettuce in the presence and absence of shading mesh. Dry matter per plant $(\mathrm{g})$

\begin{tabular}{ccc}
\hline \multirow{2}{*}{ Cultivars } & \multicolumn{2}{c}{ Shading mesh } \\
\cline { 2 - 3 } & absence & Presence \\
\hline Crisp Lucy & $0.07 \mathrm{aA}$ & $0.04 \mathrm{aA}$ \\
Crisp Vanda & $0.03 \mathrm{bB}$ & $0.07 \mathrm{aA}$ \\
\hline
\end{tabular}

Means followed by the same lower case letter for cultivars and upper case horizontal for shading mesh, do not differ by Tukey test at $5 \%$ probability. 


\section{CONCLUSIONS}

The Crisp Lucy Brown cultivar is more demanding to the luminosity and mineral nutrition in relation to the Crisp Vanda cultivar. The highest growth and productivity of the Crisp Lucy Brown cultivar was obtained in an environment without shading mesh, with fertilization before sowing at a rate of $30 \mathrm{~kg} \mathrm{ha}^{-1}$ of fowl bed and foliar fertilization with $9.1 \%$ of Ferti Garden fertilizer.

The highest development and productivity corresponded to the Crisp Vanda cultivar, obtained in an environment with shading mesh and with a single fertilization before sowing, applying $30 \mathrm{~kg}$ $\mathrm{ha}^{-1}$ of fowl bed.

RESUMO: Objetivou-se com esse trabalho avaliar a influência da adubação foliar organominaral e ambiência no cultivo da alface. O estudo foi realizado em condições de campo, em solo classificado como Neossolo Quartzarênico, com textura média e baixa disponibilidade inicial de nutrientes. O delineamento experimental utilizado foi em blocos ao acaso em fatorial $2 \times 2 \times 5$, correspondente a duas cultivares de alface (solta crespa: Vanda e repolhuda crespa: Lucy Brown), dois ambientes (presença e ausência de sombrite a 35\%) e cinco concentrações do fertilizante líquido Ferti Garden Multiuso via foliar $(0 ; 5 ; 10 ; 15$ e $20 \%$ do produto na calda), em 4 repetições, contendo 20 plantas. No preparo do solo foi realizado manualmente e fertilizado com $30 \mathrm{~m}^{3}$ hectare $^{-1}$ de esterco bovino, sendo também adotado a cobertura morta. O fertilizante foliar foi aplicado três vezes em intervalos de sete dias via pulverizador de pressão constante, a partir do 12 dias após o transplantio das mudas. Aos 33 dias após o transplantio as plantas foram colhidas e avaliadas quanto ao diâmetro da cabeça, número de folha, matéria fresca e produtividade. A cultivar Lucy Brown é mais exigente em luminosidade e nutrição mineral em relação a cultivar Vanda. O maior crescimento e produtividade da cultivar Lucy Brown é obtido na ausência de sombrite, com adubação de fundação com $30 \mathrm{~kg} \mathrm{ha}^{-1}$ de cama aviária e adubação com $9,1 \%$ do fertilizante foliar. Enquanto para cultivar solta crespa: Vanda é obtido na presença de sombrite, apenas com adubação de fundação.

PALAVRAS CHAVE: Lactuca sativa. Sombrite. Nutrição mineral. Crescimento. Produção.

\section{REFERENCES}

ALLEN, R. G.; PEREIRA, L. S.; RAES, D.; SMITH, M. Crop evapotranspiration: guidelines for computing crop water requirements. Roma: FAO, 1998. 300p.

BENINCASA, M. M. P. Análise de crescimento de plantas: Noções básicas. Jaboticabal: FUNEP, 2003. 41p.

BEZERRA NETO, F.; ROCHA, R. C. C.; NEGREIROS, M. Z.; ROCHA, R. H.; QUEIROGA, R. C. F. Produtividade de alface em função de condições de sombreamento e temperatura e luminosidade elevadas. Horticultura Brasileira, Brasília, v. 23, n. 2, p. 189-192, 2005. http://dx.doi.org/10.1590/S010205362005000200005

DONAGEMA, G. K.; CAMPOS, D. V. B.; CALDERANO, S. B.; TEXEIRA, W. G.; VIANA, J. H. M. Manual de métodos de análise de solo. 2. ed. Rio de Janeiro, RJ: Embrapa Solos, 2011. 230p.

FARIAS, D. B. S.; LUCAS, A. A. T.; MOREIRA, M. A.; NASCIMENTO, L. F. A.; SÁ, J. C. F. Cobertura do solo e adubação orgânica na produção de alface. Revista de Ciências Agrárias, Belém, v. 60, n. 2, p. 173-176, 2017.

FERREIRA, D. F. Sisvar: A computerstatisticalanalysis system. Ciência e Agrotecnologia, Lavras, v.35, n.6, p.1039-1042, 2011. http://dx.doi.org/10.1590/S1413-70542011000600001

FREITAS, G. A.; SILVA, R. R.; BARROS, H. B.; VAZ-DE-MELO, A.; ABRAHÃO, W. A. P. Produção de mudas de alface em função de diferentes combinações de substratos. Revista Ciência Agronômica, Fortaleza, v. 44, n. 1, p. 159-166, 2013. http://dx.doi.org/10.1590/S1806-66902013000100020 
GUERRA, A. M. N. M.; COSTA; A. C. M.; TAVARES, P. R. F. Atividade fotossintética e produtividade de alface cultivada sob sombreamento. Revista Agropecuária Técnica, v. 38, n. 3, p. 125-132, 2017. https://doi.org/10.25066/agrotec.v38i3.29246

HIREL, B.; TÉTU, T.; LEA, P. J.; DUBOIS, F. Improving nitrogen use efficiency in crops for sustainable agriculture. Sustainability, Basel, v. 3, n. 9, p. 1452-1485, Sep. 2011. http://dx.doi.org/doi:10.3390/su3091452

IZIDÓRIO, T. H. C.; LIMA, S. F.; VENDRUSCULO, E. P.; ÁVILA, J.; ALVAREZ, R. C. F. Bioestimulante via foliar em alface após o transplantio das mudas. Revista de AgriculturaNeotropical, Cassilândia, v. 2, n. 2, p. 49-56, 2015.

LUZ, J. M. Q.; OLIVEIRA, G.; QUEIROZ, A. A.; CARREON, R. Aplicação foliar de fertilizantes organominerais em cultura de alface. Horticultura Brasileira, Brasília, v.28, n.3, p.373-377, 2010. http://dx.doi.org/10.1590/S0102-05362010000300023

MANTOVANI, E. C.; BERNADO, S.; PALORETTI, L. F. Irrigação: princípios e métodos. 6 ed. Viçosa: Imprensa Universitária, 2006. 318.

MATOS, J. P.; CORREIA, E. C. S. S.; MONTEIRO, R. N. F.; DOMINGUES NETO, F. J.; SILVA, D. P. Floração e rendimento de frutos da abobrinha Italiana 'Daiane' sob aplicação de regulador vegetal e fertilizante foliar. Brazilian Journal of Biosystems Engineering, Tupã, v. 11, n. 1, p. 107-115, 2017.

OTONI, B. S.; MOTA. W. F.; BELFORT, G. R.; SILVA, A. R. S.; VIEIRA, J. C. B.; ROCHA, L. S. Produção de híbridos de tomateiro cultivados sob diferentes porcentagens de sombreamento. Revista Ceres, Viçosa, v.59, n.6, p.816-825, 2012. http://dx.doi.org/10.1590/S0034-737X2012000600012

PEREIRA, F. H. F.; SÁ, F. V. S.; PUIATTI, M.; FINGER, F. L.; CECON, P. R. Crescimento de planta, partição de assimilados e produção de frutos de melão amarelo sombreado por diferentes malhas. Ciência Rural, Santa Maria, v. 45, n. 10, p. 1774-1781, Oct. 2015.

RADIN, B.; REISSER, JUNIOR, C.; MATZENAUER, R.; BERGAMASCHI, H. Crescimento de cultivares de alface conduzida em estufa e a campo. Horticultura Brasileira, Brasília, v. 22, n. 2, p. 178-181, 2004. http://dx.doi.org/10.1590/S0102-05362004000200003

RAMPAZZO, R.; SEABRA JUNIOR, S.; NUNES, M. C. M.; NEVES, S. M. A. S.; FERREIRA, R. F. Eficiência de telas termorefletoras e de sombreamento em ambiente protegido tipo telado sob temperaturas elevadas. Engenharia na Agricultura, Viçosa, v. 22, n. 1, p. 33-42, 2014. https://doi.org/10.13083/14143984.v22n01a04

RICARDO, A. S.; VARGAS, P. F.; FERRARI, S.; PAVARINI, G. M. P. Telas de sombreamento no desempenho de cultivares de alface. Nucleus, Ituverava, v. 11, n. 2, p. 433-442, 2014. http://dx.doi.org/10.3738/1982.2278.1375

SANTI, A.; CARVALHO, M. A. C.; CAMPOS, O. R.; SILVA, A. F.; ALMEIDA, J. L.; MONTEIRO, S. Ação de material orgânico sobre a produção e características comerciais de cultivares de alface. Horticultura Brasileira, Brasília, v. 28, n. 1, p. 87-90, 2010. http://dx.doi.org/10.1590/S0102-05362010000100016

SANTOS, H. G.; JACOMINE, P. K. T.; ANJOS, L. H. C.; OLIVEIRA, V. A.; OLIVEIRA, J. B. Sistema Brasileiro de Classificação dos Solos. $2^{\mathrm{a}}$ ed. Rio de Janeiro: Embrapa Solos. 2013. 353p.

SCHOENINGER, V.; GIACOMIN, F.; MONTEIRO, D. P. S; SANTOS, R. F. Variação da incidência de radiação solar na cultura da alface (Lactuca sativa L. cv. Elisa). Revista Cultivando o Saber, Cascavel, v. 4, n. 1, p. 1-8, 2011. 
SILVA, A. F. T.; AMARAL, G. C.; OLIVEIRA, J. B. S.; SILVA, A. A.; BECKMANN-CAVALCANTE, M. Z. Estado nutricional de cultivares de alface em função da adubação orgânica e ambientes de cultivo. Magistra, Cruz das Almas, v. 28, n. 2, p. 221-232, 2016.

TAIZ, L.; ZEIGER, E.; MØLLER, I. M.; MURPHY, A. Plant physiology and development. $6^{\text {a }}$. ed. New York: Sinauer Associates, 2015.761p. 